\title{
Intermittent high glucose concentrations reduce neuronal precursor survival by altering the IGF system: the involvement of the neuroprotective factor DHCR24 (Seladin-1)
}

\author{
S Giannini ${ }^{1}$, S Benvenuti ${ }^{2}$, P Luciani ${ }^{2}$, C Manuelli $^{3}$, I Cellai ${ }^{2}$, C Deledda ${ }^{2}$, A Pezzatini ${ }^{1}$, G B Vannelli ${ }^{4}$, \\ E Maneschi ${ }^{2}$, C M Rotella ${ }^{1}$, M Serio $^{2}$ and A Peri ${ }^{2}$ \\ ${ }^{1}$ Diabetes and Metabolic Diseases Unit and ${ }^{2}$ Endocrine Unit, Department of Clinical Physiopathology, Center for Research, Transfer and High Education on \\ Chronic, Inflammatory, Degenerative and Neoplastic Disorders for the Development of Novel Therapies (DENOThe), ${ }^{3}$ Institute of Dermatology and \\ Venereology and ${ }^{4}$ Department of Anatomy, Histology and Forensic Medicine, University of Florence, Viale Pieraccini, 6 , 50139 Florence, Italy \\ (Correspondence should be addressed to A Peri; Email: a.peri@dfc.unifi.it)
}

\begin{abstract}
The exposure of neurons to high glucose concentrations is considered a determinant of diabetic neuropathy, whereas members of the IGF system are neurotropic factors. Here, we investigated the effects of constant and intermittent high glucose concentrations on IGF1 and IGF-binding proteins (IGFBPs) in human neuroblast long-term cell cultures fetal neuroepithelial cells (FNC). These cells express the IGF1 receptor, and express and release in the culture medium IGFBP2, IGFBP4, and IGF1. The release of IGF1 was significantly increased by $17 \beta$-estradiol $(10 \mathrm{nM})$. IGF1 $(100 \mathrm{nM})$ treatment determined a significant increase of IGFBP2 and a decrease of IGFBP4 release. In addition, IGF1 (1-100 nM) stimulated FNC cell proliferation in a dose-dependent manner. We hypothesized that this effect may be, at least partially, due to IGF1-induced up-regulation of the expression of the Alzheimer's disease related gene SELADIN-1
\end{abstract}

(now known as DHCR24), which acts as a pro-survival factor for neuronal cells. Conversely, the exposure to intermittent $(20 / 10 \mathrm{mM})$, but not stable $(20 \mathrm{mM})$, high glucose concentrations decreased the release of IGF1 and IGFBP2 in the culture medium and inhibited FNC growth by inducing apoptosis. The latter was prevented by the addition of IGF1 to the culture medium. Furthermore, high glucose concentrations reduced the expression of DHCR24. In conclusion, our results indicate for the first time that intermittent high glucose concentrations, similar to those observed in poorly controlled diabetic patients, may contribute to the development of diabetic neuropathy by interfering with the tropic effects exerted by the IGF system, and suggest the involvement of the neuroprotective factor DHCR24.

Journal of Endocrinology (2008) 198, 523-532

\section{Introduction}

Neuropathy can be a highly debilitating clinical condition for diabetic individuals. Although several mechanisms are involved in this complication, most pathogenic theories generally accept that damage to nerves is a direct or indirect effect of glucose levels (Tomlinson \& Gardiner 2008). In fact, altered biological products such as advanced glycation end products formation, cellular accumulation of polyols, decreased myo-inositol content, impaired Schwann cell function, and microangiopathy with ischemia have been proposed to cause neuropathy (Vincent et al. 2004, Ho et al. 2006). In vivo experimental diabetes clearly determined an impairment of axonal regeneration, and neuron loss at various stages of degeneration has been reported in the presence of chronic high glucose (Yagihashi et al. 1990, Toth et al. 2004), whereas in vitro studies showed that intermittent high glucose is more toxic than constant high glucose concentrations for human cells (Piconi et al. 2006).
The insulin-like growth factor (IGF) system consists of IGF1, IGF2, IGF1 receptor (IGF1R), IGF2R, and some protein carriers named IGF-binding proteins (IGFBPs 1-6). Most of the IGFs in biological fluids and in vitro cell cultures form complexes with IGFBPs that bind to IGFs with affinities 10- to 100-fold greater than the IGF1R, thus modulating the bioavailability of IGFs (Mohan \& Baylink 2002). Several studies have documented the presence of IGFs in the central nervous system (CNS) and, although the precise roles of these growth factors remain to be elucidated, there is evidence that this system plays an important role in neuronal development, metabolism, survival, and regeneration (Matthews \& Feldman 1996, Russo et al. 2004, 2005). On the contrary, little is known about the types and the regulation of IGFBPs in human neuronal cells. Under basal conditions, human neuroblastoma cells have been demonstrated to secrete a large amount of IGFBP2, a lower amount of IGFBP4, and traces of IGFBP6 (Babajko et al. 1997). IGFBP2 is the most representative IGFBP in the cerebrospinal fluid 
suggesting an important role in the CNS (Roghani et al. 1993). IGF1 and other growth factors have been demonstrated to differently regulate the levels of IGFBPs in the CNS depending on the type of neuronal or glial cells studied (Pons \& Torres-Aleman 1992, Kummer et al. 1996).

SELADIN-1 (for SELective Alzheimer's disease INdicator1 that is now known as DHCR24) is a recently described gene found to be down-regulated in brain regions affected by Alzheimer's disease (Greeve et al. 2001). A neuroprotective role has been described for this gene. In fact, when DHCR24 was overexpressed in neuroglioma $\mathrm{H} 4$ cells it counteracted the toxicity of $\beta$-amyloid deposits and oxidative stress (Greeve et al. 2001). The biological effects of DHCR24 appear to be due, at least in part, to its anti-apoptotic activity related to the inhibitory effect on the activation of CASP3. We have demonstrated previously that $17 \beta$-estradiol increases cell proliferation, whereas it counteracts $\beta$-amyloid-induced apoptosis in human fetal neuroepithelial cells (FNC) and up-regulates the expression of the DHCR24 gene. These findings suggested that this gene may be a mediator of the prosurvival effects of estrogen in the brain (Benvenuti et al. 2005). This hypothesis was supported by the very recent finding that DHCR 24 silencing abolishes the protective effects of estrogen in FNC cells (Luciani et al. 2008). These cells are GNRH1secreting neuroblast long-term cell cultures, previously isolated from human fetal olfactory epithelium (Vannelli et al. 1995). FNC show unique features, because they synthesize both neuronal proteins and olfactory markers and respond to odorant stimuli, suggesting their origin from the stem cell compartment that generates mature olfactory receptor neurons. Interestingly, there is evidence of a tight link between estrogen and the IGF system in the CNS in terms of neuronal cell differentiation, survival, and regeneration (Mendez et al. 2003, 2006).

The aim of this study was to clarify the involvement of the IGF system in glucose-related neuropathy. To this purpose, we used FNC to i) characterize the IGF system in this neuronal cell model; ii) determine whether IGF1 has prosurvival effects in these cells; iii) assess whether the exposure to constant and intermittent high glucose concentrations, similar to those observed in poorly controlled diabetics, affects the integrity of the IGF system; and iv) determine whether IGF1 and high glucose concentrations affect the expression of the DHCR24 gene.

\section{Materials and Methods}

\section{Cell cultures}

The primary neuroblast long-term cell culture FNC was established, cloned, and propagated in vitro from human fetal olfactory neuroepithelium (Vannelli et al. 1995). FNC cells synthesize both neuronal proteins and olfactory markers and respond to odorant stimuli, suggesting that their origin from the stem cell compartment that generates mature olfactory receptor neurons. In addition, they display neuroendocrine features (Maggi et al. 2000). FNC cell cultures were propagated at $37^{\circ} \mathrm{C}$ in $5 \% \mathrm{CO}_{2}$ in Coon's modified Ham's F-12 medium (Sigma Chemicals Co.), with $1 \cdot 802 \mathrm{~g} / 1$ glucose, $10 \%$ fetal bovine serum (HyClone, Logan, UT, USA), and antibiotics (penicillin, $100 \mathrm{IU} / \mathrm{ml}$; streptomycin $100 \mu \mathrm{g} / \mathrm{ml}$ ). The B4 clone, showing the highest levels of expression of neuronal and olfactory markers (Vannelli et al. 1995), was used in this study.

\section{Determination of IGF1R $m R N A$ and protein levels}

Total RNA was extracted from cells using RNeasy kit (Qiagen) and treated with DNase I (Qiagen) to eliminate possible genomic DNA contamination. cDNA of each sample was synthesized from $1 \mu \mathrm{g}$ total RNA using TaqMan Reverse Transcription Reagents (Applied Biosystems, Foster City, CA USA), following the manufacturer's protocol. Real-time RT-PCR was performed using an ABI PRISM 7900HT Sequence Detection System (Applied Biosystems), according to the manufacturer's instructions. All PCR amplifications were performed on MicroAmp optical 96-well reaction plate with Taqman Universal Master Mix (Applied Biosystems) and using Assay on Demand (Applied Biosystems). The PCR was performed using the template cDNA with specific primers for human IGF1 receptor (Forward: 5'-TTA AAA TGG CCA GAA CCT GAG-3'; Reverse: $5^{\prime}$-ATT ATA ACC AAG CCT CCC AC- $\left.3^{\prime}\right)$. Each assay was carried out in duplicate and included a no-template sample as negative control. RT-negative samples were used to demonstrate that the signals obtained were RT dependent. Relative expression of mRNA levels were determined by comparing experimental determinations to a standard curve generated using serial dilutions of cDNAs obtained from human leukocytes (Liotta et al. 2007).

For immunoblot analysis of IGF1R, cell lysates were prepared as described previously (Cho et al. 2003). Total cell lysates were resolved on 4-20\% SDS-PAGE and transferred onto polyvinylidene fluoride membranes (Millipore, Beford, MA, USA). The blots were blocked for $1 \mathrm{~h}$ in TBS-T (20 mmol/1 Tris-HCl, pH 7.5, 150 mmol/1 NaCl, $1 \mathrm{~g} / 1$ Tween 20) containing $50 \mathrm{~g} / 1$ non-fat dry milk powder and incubated for $1 \mathrm{~h}$ with anti-IGF-IR $\beta$ (1:500, Santa Cruz Biotechnology, Santa Cruz, CA, USA) antibody. The blots were then incubated with anti-mouse or anti-rabbit HRPconjugated antibody. Signals were detected by chemiluminescence using SuperSignal West Dura Extended Duration Substrate (Pierce, Rockford, IL, USA).

\section{Collection of conditioned medium (CM), identification, and immunocharacterization of IGFBPs}

Cells were seeded in $25 \mathrm{~cm}^{2}$ tissue culture flasks at a density of $35 \times 10^{3}$ cells $/ \mathrm{cm}^{2}$ in regular medium. After $24 \mathrm{~h}$, the cells were washed with PBS and cultured in $1.5 \mathrm{ml}$ serum-free culture medium for $48 \mathrm{~h}$ (basal condition) or in serum-free culture medium for $24 \mathrm{~h}$, and then in serum-free culture 
medium containing 100 nM IGF1 (Sigma Chemicals Co.) for an additional $24 \mathrm{~h}$. CM was then collected and stored at $-80^{\circ} \mathrm{C}$, as described previously (Giannini et al. 1994). After the collection of CM, cell numbers were determined and the volume for analysis adjusted accordingly. IGFBPs in the CM were examined by western ligand blotting, carried out according to the method of Hossenlop et al. (1986). Briefly, $100 \mu \mathrm{lCM}$, together with pre-stained molecular weight marker proteins (Bio-Rad) underwent 12\% SDS-PAGE in nonreducing conditions and subsequent transfer onto nitrocellulose membranes (Sartorius AG, Gotingen, Germany). The membranes were then incubated with ${ }^{125}$ I[IGF2] (Amersham). Protein band intensity was analyzed by scanning densitometry of the original autoradiographic film, after 3 days of exposure, with a Flowvision densitometer (Lynx, San Mateo, CA, USA). To quantify the intensity of radioactivity of various IGFBPs, several autoradiographs developed after different times of exposure of the same blot were measured, and data within a linear range were used.

For immunoblotting, CM was subjected to SDS-PAGE under non-reducing conditions and then electrophoretically transferred onto a nitrocellulose membrane as described above for the western ligand blotting. Polyclonal antibodies against IGFBP1 to IGFBP6 were purchased from UBI (Lake Placid, NY, USA) and goat antibody immunoglobulin G conjugated with alkaline phosphatase was obtained from Sigma Chemicals Co. The signals were detected according to the manufacturer's instructions.

For glycosylation studies, a 10-fold concentrated lyophilized FNC serum-free CM was analyzed as follows: a $2 \mathrm{mg} / \mathrm{ml}$ solution of FNC CM were prepared and $5 \mu 17 \cdot 5 \% \mathrm{NP}-40$ and then $8 \mu \mathrm{l} \mathrm{N}$-glycanase enzyme (Genzyme Co., Cambridge, MA, USA) were added to $10 \mu \mathrm{l}$ of the above obtained solution. After the addition of $7 \mu \mathrm{l}$ distilled water, the solution was incubated for 12 and $24 \mathrm{~h}$ at $37^{\circ} \mathrm{C}$. The reaction was finally stopped by the addition of a proper amount of PAGE loading buffer and the samples were analyzed by ligand blot after SDSPAGE (Giannini et al. 1999).

\section{IGF1 determination by ELISA}

Secreted IGF1 was determined using acid ethanol extraction (Daughaday et al. 1980) and the Quantikine human IGF1 kit (R\&D system, Minneapolis, MN, USA). An aliquot of $600 \mu \mathrm{l}$ of the above described CM, exposed to $17 \beta$-estradiol, high glucose, or intermittent high glucose concentrations, was lyophilized to a dry pellet. An aliquot of $20 \mu \mathrm{l}$ water was added to resuspend the pellet. An aliquot of $80 \mu \mathrm{l}$ of $12.5 \% 2 \mathrm{M}$ formic acid $/ 87 \cdot 5 \%$ ethanol was added and incubated for $30 \mathrm{~min}$ at room temperature to avoid the IGFBP complexes and to free IGF1. The solution was centrifuged and the supernatant was neutralized by adding $0 \cdot 4$ volume of $0 \cdot 855 \mathrm{M}$ Tris base. Seven volumes of $1 \mathrm{mg} / \mathrm{ml} \mathrm{BSA}$ with $500 \mathrm{ng} / \mathrm{ml}$ IGF2 in $0.1 \mathrm{M}$ Tris ( $\mathrm{pH} 7 \cdot 4)$ were added; $50 \mu$ lof the prepared sample were used in each well of the Quantikine kit following the manual instructions for each experimental condition.
Cell growth

For cell growth experiments, $5 \times 10^{4}$ cells were seeded onto 6 -well plates in growth medium. After $24 \mathrm{~h}$, the growth medium was removed, the cells were incubated in the same medium with different stimuli: IGF1 (Sigma Chemicals Co.), recombinant human IGFBP2 (UBI), and $\alpha$ IR 3 antibody (kind gift from Prof Mario Maggi, University of Florence, Italy). During the prolonged (5 days) glucose cell culture experimental protocol, three groups of FNC were considered, each receiving the following fresh medium every $24 \mathrm{~h}: 1$ ) continuous normal glucose medium $(10 \mathrm{mM}) ; 2)$ continuous high glucose medium $(20 \mathrm{mM})$; and 3) intermittent high glucose media $(20 / 10 \mathrm{mM})$ alternating every $24 \mathrm{~h}$. Osmotic control was assured by incubating FNC with equimolar concentrations of mannitol, both continuously and in an alternating manner. The cells were then trypsinized and counted using a hemocytometer. For each experimental point, the mean value from at least five different fields for each well was considered. Each determination was repeated in duplicate. The results of the experiments were expressed as growth percentage ( \pm s.E.M.) versus the corresponding control.

\section{TUNEL analysis for the determination of apoptotic cells}

Apoptosis was analyzed by TUNEL analysis, using a commercially available detection kit (FragEL DNA Fragmentation Detection Kit, Oncogene Research Products, Boston, MA, USA). FNC cells were cultured in chamber slides for 5 days. Fresh medium was changed every $24 \mathrm{~h}$ and four groups were considered: 1) continuous normal glucose medium $(10 \mathrm{mM})$; 2) intermittent high glucose media $(20 / 10 \mathrm{mM})$ alternating every $24 \mathrm{~h}$; 3) IGF1 (10 $\mathrm{nM})$; and 4) IGF1 (10 nM) and intermittent $20 / 10 \mathrm{mM}$ glucose. Three experiments were performed. Apoptotic cells/field were counted in twenty fields $(20 \times)$ and the results were expressed as percentage of apoptotic cells/field.

\section{Quantitative real-time RT-PCR for DHCR24 transcript}

The absolute quantification of DHCR24 mRNA was performed by real-time RT-PCR, based on TaqMan technologies, as described previously (Luciani et al. 2004). Total RNA to be subjected to reverse transcription was extracted from FNC in basal condition and after IGF1 or high glucose concentrations exposure. The results were referred to microgram of total RNA. The experiments $(n=3)$ were run in triplicates.

\section{Statistical analysis}

Data were expressed as mean \pm s.E.M. Statistical differences were analyzed using one-way analysis of variance. The significant level was taken at $P<0 \cdot 05$. All statistical tests were performed with the program, Statistical Package for Social Sciences (SPSS version 12.0; SPSS, Chicago, IL, USA). 


\section{Results}

\section{Characterization of the IGF system in FNC}

No previous study characterized the IGF system in the cell model we used, i.e. FNC. Initially, the presence of IGF1R was investigated. The amount of mRNA was determined by real-time RT-PCR. IGF1R transcript was detectable in FNC and the level of expression was about four-fold higher than in a human cell line from glomerular endothelial cells (GENC), previously obtained in our laboratory and used as the positive control (Giannini et al. 1999; Fig. 1A). Western immunoblot analysis of the IGF1R in cell lysates of FNC confirmed the presence of a band of about $95 \mathrm{kDa}$, corresponding to the mature form of the IGF1R and a faint band of $200 \mathrm{kDa}$ that has been reported to correspond to a precursor form of this receptor (Kim et al. 2005; Fig. 1B).

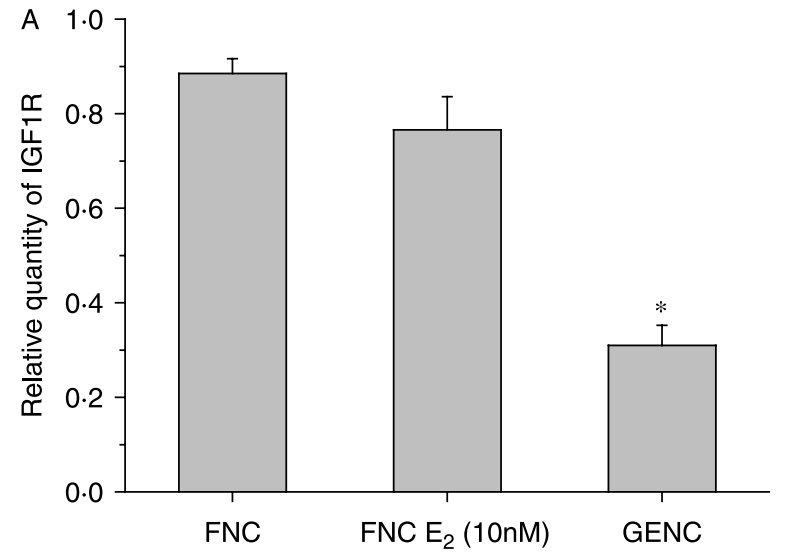

B

IGF1R precursor

Mature IGF1R

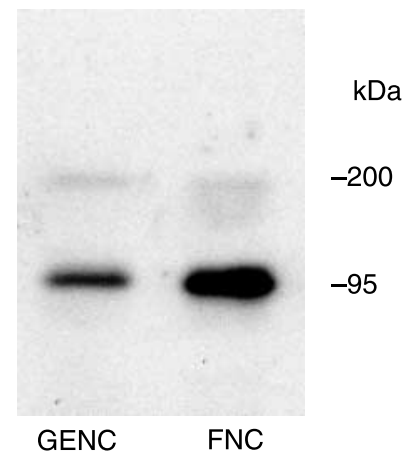

Figure 1 (A) Expression of IGF1R mRNA in FNC, FNC exposed to $17 \beta$-estradiol $\left(\mathrm{E}_{2} ; 10 \mathrm{nM}\right)$, and GENC used as the positive control, as assessed by quantitative RT-PCR. Relative quantity of IGF1R indicates that mRNA levels were determined by comparing experimental determinations to a standard curve generated using serial dilutions of cDNAs obtained from human leukocytes (Liotta et al. 2008). ${ }^{*} P<0 \cdot 05$ (B) Expression of IGF1R precursor protein and mature IGF1 R protein in FNC and GENC. The western blot shown in the figure is representative of three independent experiments.
With regard to IGFBPs, after $48 \mathrm{~h}$ in serum-free medium, western ligand blot analysis revealed the presence of two major IGFBP species of 34 and $24 \mathrm{kDa}$ and a faint $32-30 \mathrm{kDa}$ doublet in FNC (Fig. 2A). The $34 \mathrm{kDa}$ band with the migration pattern typical of IGFBP2 was recognized by the anti-IGFBP2 antibody (Fig. 2B). This antibody did not recognize other proteins with a lower molecular weight. The $24 \mathrm{kDa}$ band, with migration characteristics of IGFBP4, was identified as such by the specific antibody (Fig. 2B). However, this antibody also cross-reacted with the $32-30 \mathrm{kDa}$ doublet, which could correspond to the glycosylated form of IGFBP4 (Fig. 2B; Babajko et al. 1997), as confirmed by $N$-glycanase treatment of the CM, which determined the disappearance of

\section{A}

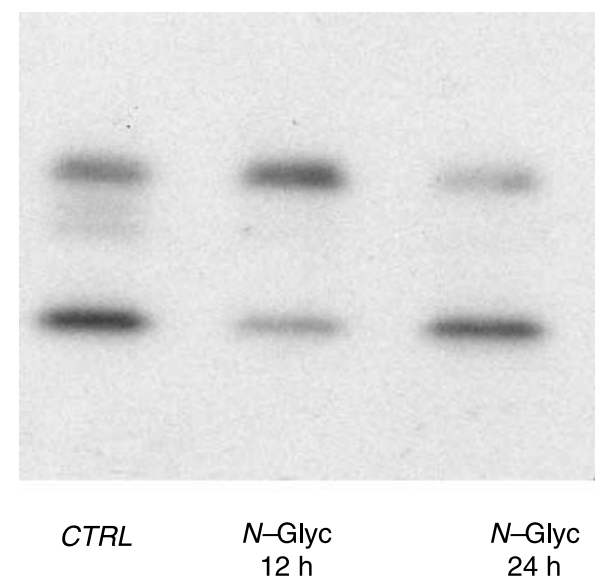

B

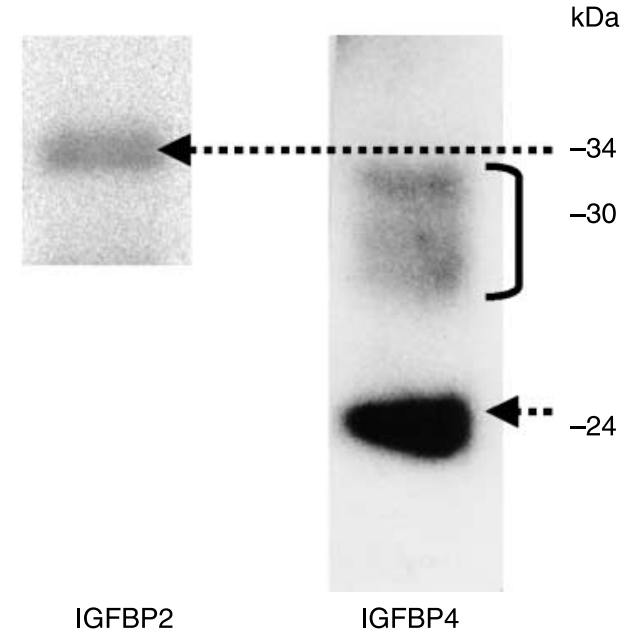

$\mathrm{kDa}$

Figure 2 IGFBPs characterization in FNC. (A) ${ }^{125}$ I[IGF2] ligand blot of FNC CM without (CTRL) or with $\mathrm{N}$-glycanase ( $\mathrm{N}$-Glyc) treatment for 12 and $24 \mathrm{~h}$. The molecular weight of the detected signals is reported on the right-hand side of the figure. (B) Immunoblotting for the characterization of the IGFBPs released by FNC. Immunoreactive signals specific for IGFBP2 and IGFBP4, and the 32-30 kDa doublet are shown. 
this band in the western ligand blot analysis (Fig. 2A). No signals, instead, were obtained with anti-IGFBP1, $-3,-5$, or -6 antibodies (data not shown). In the presence of $100 \mathrm{nM}$ IGF1, western ligand blot analysis of the IGFBPs released in the CM showed an increased intensity of the $34 \mathrm{kDa}$ signal (IGFBP2) band with a concomitant dramatic reduction of the $24 \mathrm{kDa}$ signal (IGFBP4; Fig. 3). In addition, the exposure to IGF1 markedly increased the signal corresponding to the 32-30 kDa doublet. The densitometry of the signals showed in Fig. 3 is reported in Table 1. Immunoblot analysis, using the anti IGFBP4 antibody, confirmed the results of western ligand blot analysis, with regard to the variations of the 24 and 32-30 kDa signals upon IGF1 treatment (data not shown).

Furthermore, the production of IGF1 by FNC cells was assessed. Detectable levels of immunoreactive IGF1 were found in the culture medium (Fig. 4). According to previous evidence that a cross-talk between the IGF system and estrogen in the brain occurs (Mendez et al. 2003, 2006), the effect of $17 \beta$-estradiol on IGF1 production was determined. The exposure of FNC to $17 \beta$-estradiol $(10 \mathrm{nM})$ significantly increased the release of IGF1 in the culture medium (Fig. 4). Conversely, estrogen exposure did not significantly alter the amount of expression of IGF1R (Fig. 1A).

\section{Effect of IGF1 on FNC cell proliferation}

The effect of increasing concentrations of IGF1 on FNC cell proliferation was investigated in FNC cells maintained in CM. The results of these experiments are shown in Fig. 5. IGF1 significantly increased the cell number in a dosedependent manner with a maximum effect at $10 \mathrm{nM}(2 \cdot 1$-fold

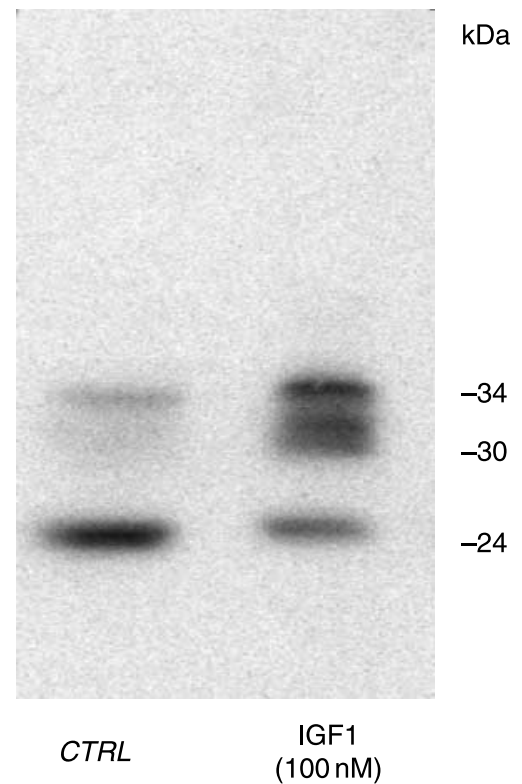

Figure $3{ }^{125}$ I[IGF2] ligand blot of FNC CM harvested after 48-h serum-free culture in the presence or not (CTRL) of 100 nM IGF1.
Table 1 Densitometric quantification of western ligand blot showing the effect of insulin-like growth factor 1 (IGF1) on IGFbinding proteins (IGFBPs) modulation in fetal neuroepithelial cells (FNC; Fig. 3)

\begin{tabular}{llll} 
& \multicolumn{1}{c}{ Control } & & IGF1 \\
\cline { 2 - 2 } IGFBP4 & $200 \cdot 3 \pm 37 \cdot 8$ & & $83 \pm 11^{*}$ \\
$32-30 \mathrm{kDa}$ doublet & $10 \cdot 6 \pm 2 \cdot 9$ & & $689 \cdot 3 \pm 68 \cdot 7^{+}$ \\
IGFBP2 & $41 \cdot 6 \pm 5 \cdot 5$ & & $496 \cdot 3 \pm 55 \cdot 6^{+}$
\end{tabular}

Data are expressed as mean values \pm S.E.M. of three different experiments. ${ }^{*} P<0 \cdot 05 ;{ }^{\dagger} P<0 \cdot 01$ versus control.

versus untreated cells). The addition of the monoclonal antibody $\alpha$ IR 3, which specifically inhibits IGF1 binding to its receptor, blunted the effect of IGF1 $(10 \mathrm{nM})$. By contrast, the co-presence of an equimolar concentration $(10 \mathrm{nM})$ of IGF1 and recombinant IGFBP2 maintained the stimulatory effect of IGF1 on cell growth $(2 \cdot 05$-fold versus untreated FNC cells).

\section{Effect of glucose exposure on FNC cell proliferation and} on IGF1/IGFBPs release

The exposure to a constant high $(20 \mathrm{mM})$ glucose concentration did not modify the growth profile of FNC compared with control untreated cells. Instead, when the cells were alternatively exposed to intermittent high glucose concentrations $(20 / 10 \mathrm{mM})$, the number of cells at the end of the treatment was significantly lower compared with untreated cells (Fig. 6). The inhibitory effect of 20/10 mM glucose on cell growth was effectively counteracted by IGF1 treatment $(10 \mathrm{nM})$. Osmotic control with mannitol did not significantly affect the cell number.

The effect of the 20 and $20 / 10 \mathrm{mM}$ glucose exposure on IGFBPs secretion was also checked (Fig. 7). The amount of IGFBP4 in the CM was not modified by glucose exposure,

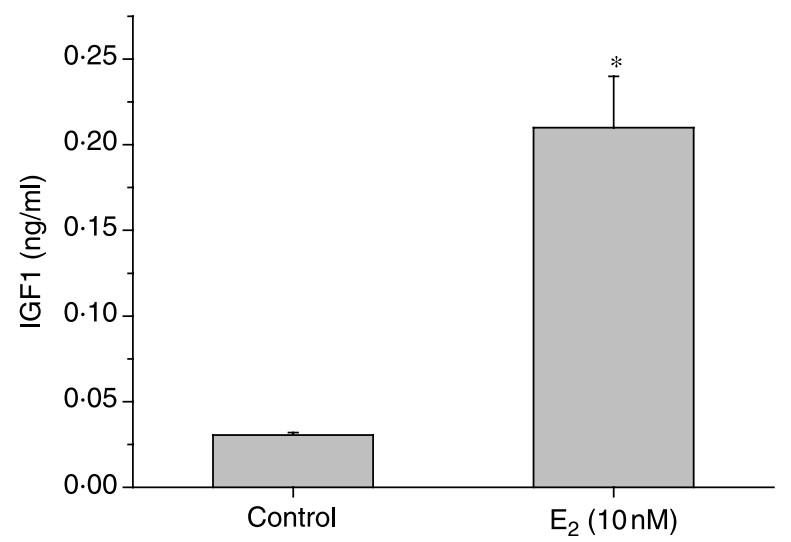

Figure 4 Amount of IGF1 released by FNC in the culture medium in basal conditions (control) and after treatment with $17 \beta$-estradiol $\left(\mathrm{E}_{2}\right.$; $10 \mathrm{nM}$ ). The results are reported as mean values \pm s.E.M. of three different experiments. $* P<0 \cdot 05$. 


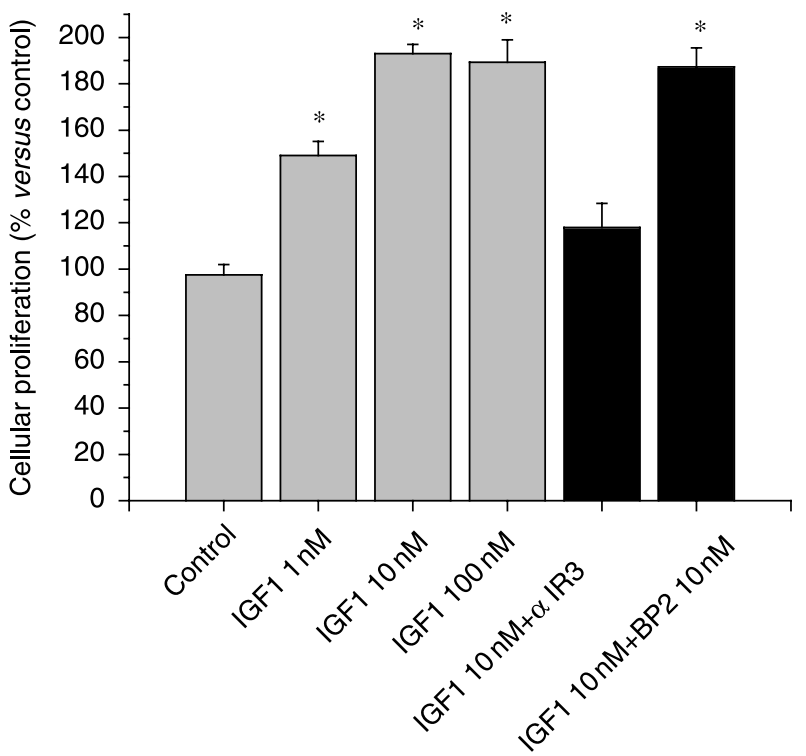

Figure 5 Effect of IGF1 on FNC cell growth. The results are reported as mean values + S.E.M. of three different experiments and are reported as percentage of cell number versus untreated cells (control considered as $100 \%$ ). ${ }^{*} P<0 \cdot 05$.

whereas the intensity of the IGFBP2 and of the $32-30 \mathrm{kDa}$ doublet signals was significantly reduced upon $20 / 10 \mathrm{mM}$ glucose exposure, as determined by densitometric analysis, reported in Table 2. Osmotic control with mannitol did not affect the IGFBPs levels.

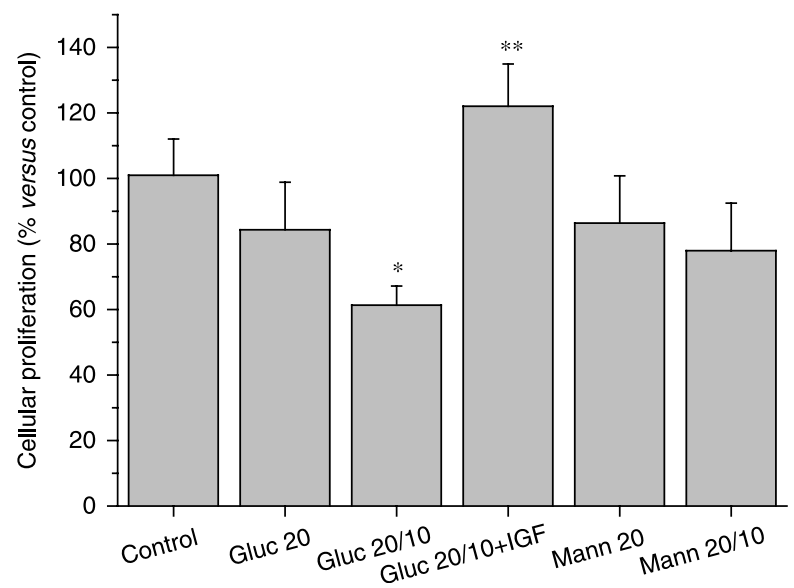

Figure 6 Effect of stable high $(20 \mathrm{mM})$ and oscillating high glucose (Gluc; 20/10 mM) concentrations on FNC cell growth. The effect of the exposure to IGF1 $(10 \mathrm{nM})$ in addition to glucose $20 / 10 \mathrm{mM}$ is also shown. Equimolar concentrations of mannitol (mann) were used as osmotic control. The results are reported as mean values \pm S.E.M. of three different experiments and are reported as percentage of cell number versus untreated cells (control, considered as $100 \%$ ). ${ }^{*} P<0 \cdot 05$ versus control; ${ }^{* *} P<0 \cdot 05$ versus glucose $20 / 10 \mathrm{mM}$.

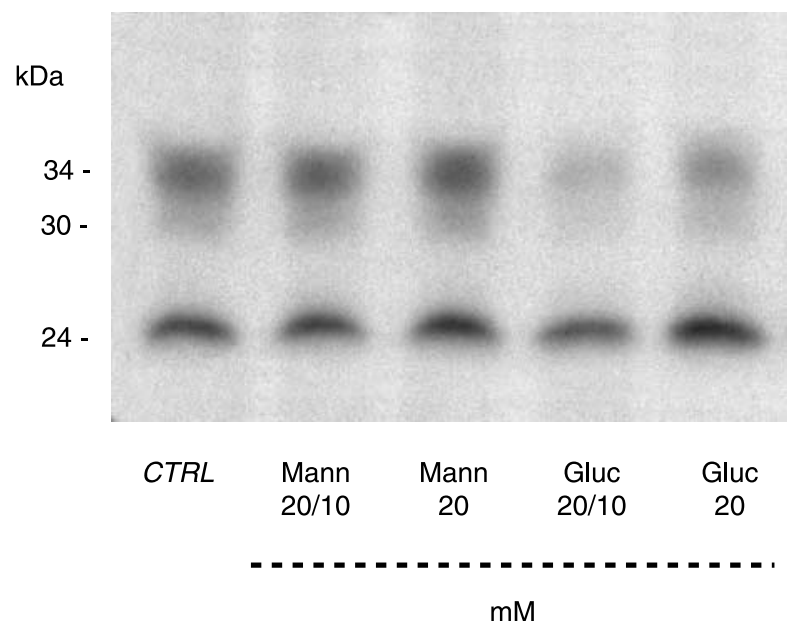

Figure $7{ }^{125}$ [IIGF2] Western ligand blot of FNC CM in basal conditions (CTRL) or after exposure to alternating high $(20 / 10 \mathrm{mM})$ and constant high $(20 \mathrm{mM})$ glucose (Gluc) concentrations.

Equimolar concentrations of mannitol (Mann) were used as osmotic control. The molecular weight of the detected signals is reported on the left-hand side of the figure.

Interestingly, the amount of IGF1 released in the CM was also affected by the exposure to glucose; in particular, a significant reduction was obtained upon exposure to glucose 20/10 mM (Fig. 8).

\section{Effect of IGF1 and glucose on FNC cell apoptosis}

In order to determine whether the inhibitory effect of intermittent high glucose concentrations on FNC cell growth was influenced by altered cell survival, apoptosis was evaluated by TUNEL analysis. The exposure to $20 / 10 \mathrm{mM}$ glucose significantly increased the number of apoptotic cells. As already observed in cell proliferation experiments, IGF1 $(10 \mathrm{nM})$ was able to counteract the pro-apoptotic effect of intermittent high glucose concentrations (Fig. 9).

\section{Effect of IGF1 and glucose on DHCR24 expression in FNC}

To examine whether the IGF system affects the DHCR24 gene expression in FNC, quantitative RT-PCR was performed. In these experiments, IGF1 $(10 \mathrm{nM})$ and IGFBP2 $(10 \mathrm{nM})$, alone or in combination, were used. IGF1 increased the amount of DHCR24 mRNA by $\sim 2 \cdot 4-$ fold compared with untreated FNC cells. Conversely, the treatment with IGFBP2 had no significant effect on DHCR24 mRNA (Fig. 10). The simultaneous exposure to IGF1 and IGFBP2 did not modify the effect observed in the presence of IGF1 alone. At variance with the stimulatory effect of IGF1, both glucose 20/10 and $20 \mathrm{mM}$ were able to determine a statistically significant reduction of the amount of DHCR24 expression (Fig. 10). 
Table 2 Densitometric quantification of western ligand blot showing the effect of alternating high (20/10 mM) or constant high (20 mM) glucose (Gluc) concentrations, or equimolar concentrations of mannitol (Mann), on insulin-like growth factor-binding proteins (IGFBPs) release. Data are expressed as mean values \pm S.E.M. obtained from triplicate determinations (Fig. 7)

\begin{tabular}{|c|c|c|c|c|c|}
\hline & Control & Mann 20/10 & Mann 20 & Gluc 20/10 & Gluc 20 \\
\hline IGFBP4 & $180 \pm 30 \cdot 6$ & $168 \pm 19 \cdot 6$ & $188 \pm 23 \cdot 1$ & $147 \pm 18 \cdot 5$ & $17 \cdot 8 \pm 26 \cdot 6$ \\
\hline 32-30 kDa doublet & $16 \pm 2 \cdot 9$ & $12 \pm 2 \cdot 3$ & $23 \pm 4$ & $3 \pm 1 \cdot 2 *$ & $15 \pm 4 \cdot 6$ \\
\hline IGFBP2 & $89 \pm 14 \cdot 4$ & $96 \pm 13 \cdot 3$ & $94 \pm 17 \cdot 9$ & $12 \pm 1 \cdot 7^{*}$ & $59 \pm 6 \cdot 9$ \\
\hline
\end{tabular}

$* P<0 \cdot 05$ versus control.

Conversely, the exposure to mannitol did not modify the amount of mRNA (data not shown).

\section{Discussion}

The pathogenesis of diabetic neuropathy is complex and involves different molecular mechanisms. IGF1, together with its related IGFBPs, is well recognized as a potent physiological neurotropic factor because of its ability to promote the proliferation, survival, migration, and differentiation of immature glial and neuronal cells (Russo et al. 2005). The role of the IGFBPs in these processes remains unclear, but it is likely to involve the transport and targeting of IGF1 to its receptor (Russo et al. 2005). IGF1 has a well-demonstrated protective effect on neuronal cells even when exposed to many biological insults (Matthews et al. 1997, Russo et al. 2004, Willaime-Morawek et al. 2005). Nevertheless, a few data on the protective effect of IGF1 in human neuronal cells in the presence of high glucose concentrations are available (Gustafsson et al. 2004) and, to our knowledge, no study has assessed the modification of IGF1 or IGFBPs levels in neuronal cells during rapid changes of glucose concentration, as it might occur in poorly controlled diabetes. To clarify this issue, in the present study, we used a unique human cell model, i.e. FNC.

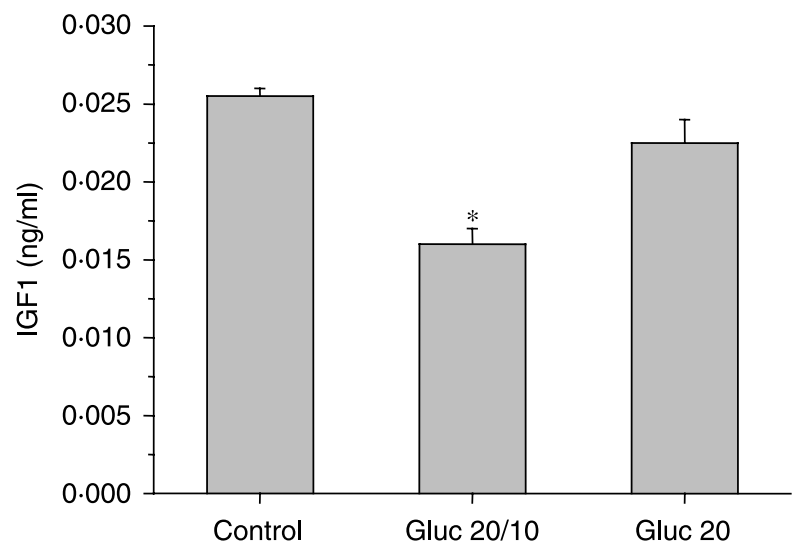

Figure 8 Amount of IGF1 released by FNC in the culture medium in basal conditions (control) and after treatment with alternating high $(20 / 10 \mathrm{mM})$ or constant high $(20 \mathrm{mM})$ glucose (Gluc) concentrations. The results are reported as mean values \pm S.E.M. of three different experiments. ${ }^{*} P<0 \cdot 05$ versus control.
First, we characterized the IGF system in these cells and we found that FNC express the IGF1 receptor, which is known to be variably expressed in the developing brain, with a higher level in the early stages of embryogenesis (Gammeltoft $e t$ al. 1985). With regard to IGFBPs, the presence of low molecular weight IGFBPs $(24-34 \mathrm{kDa})$ in the CM of neuronal cells has been described (D'Ercole et al. 1996). The most abundant immunocharacterized IGFBPs in these cells are IGFBP2, IGFBP4, and IGFBP5 (Han et al. 1996). For the other IGFBPs, the demonstration of their presence is limited, variable, and when expressed their levels are low (Naeve et al. 2000). Under particular experimental conditions, the induction of IGFBP6 that is not normally expressed in the CNS has been reported (Zhou et al. 2001). In the present study, we identified in the CM of FNC cells two major bands of 24 and $34 \mathrm{kDa}$ immunocharacterized as IGFBP4 and IGFBP2 respectively. These data confirm a previous report on neuroblastoma cells (SK-N-SH) that, under basal conditions, secrete these two IGFBPs (Menouny et al. 1997). However, in agreement with another human neuroblastoma cell line ( $\mathrm{SH}-$ SY5Y), in the CM of FNC we detected an additional weak signal migrating as a doublet around $32-30 \mathrm{kDa}$, which we characterized as the $\mathrm{N}$-glycosylated form of IGFBP4 (Babajko et al. 1997). IGF1 treatment increased the amount of immunoreactive IGFBP2 in the CM, whereas it decreased

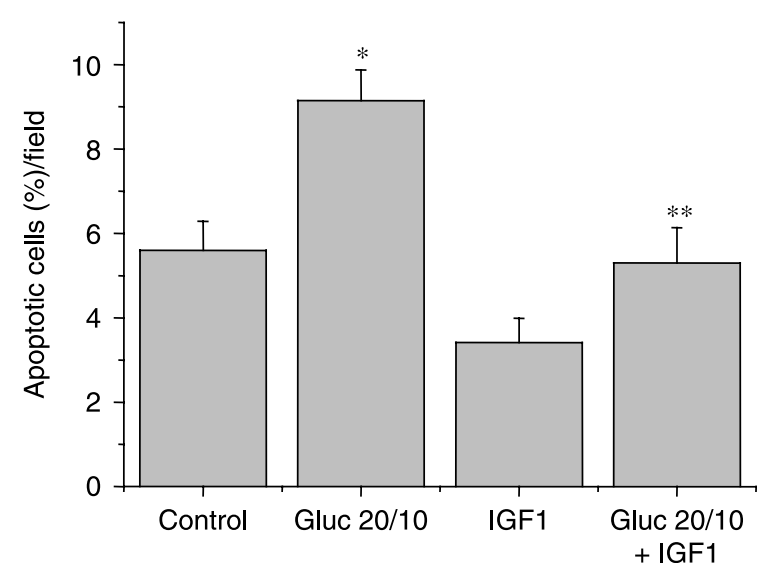

Figure 9 Amount of apoptotic cells, as detected by TUNEL analysis, in basal conditions (control) and after exposure to glucose (Gluc) 20/10 mM, IGF1 (10 nM), or Gluc 20/10 mM + IGF1 (10 nM). $* P<0 \cdot 05$ versus control; ${ }^{* *} P<0 \cdot 05$ versus glucose $20 / 10 \mathrm{mM}$. 


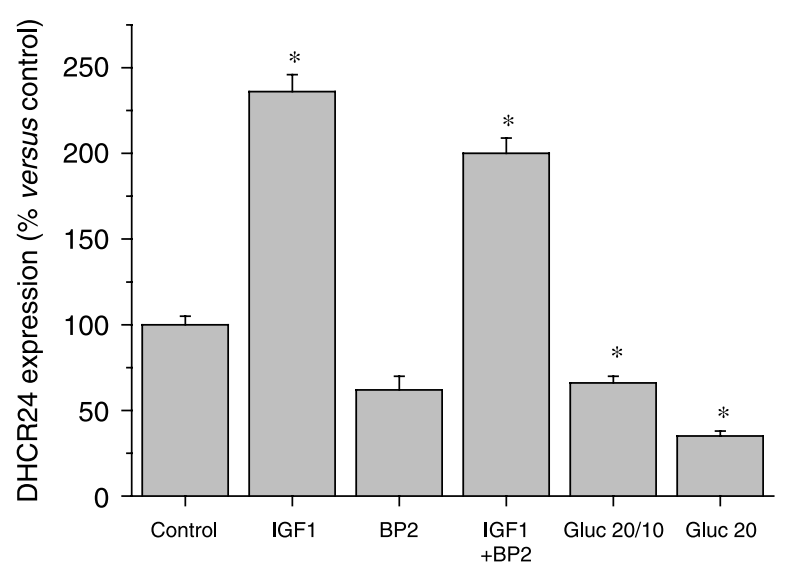

Figure 10 Quantification of DHCR24 mRNA by real-time RT-PCR in untreated FNC (control), or upon exposure to $10 \mathrm{nM} \mathrm{IGF1,} 10 \mathrm{nM}$ IGFBP2 (BP2), $10 \mathrm{nM}$ IGF1 + $10 \mathrm{nM}$ IGFBP2, alternating high $(20 / 10 \mathrm{mM})$ or constant high $(20 \mathrm{mM})$ glucose (Gluc) concentrations. ${ }^{*} P<0 \cdot 05$.

the amount of IGFBP4. The altered ratio between these two IGFBPs may account, at least in part, for the observed stimulatory effect of IGF1 on FNC cell proliferation, which confirmed the large number of in vitro studies demonstrating that IGF1 promotes cell proliferation in neuronal cells (Russo et al. 2005). In fact, IGFBP2 is produced in various regions of the CNS, it is one of the major IGFBPs in the cerebrospinal fluid, and its mRNA is detectable in abundance in some brain regions with higher dynamic remodeling such as the olfactory bulb (D'Ercole et al. 1996). IGFBP2 is associated with membrane proteoglycans in neuronal cells where the complex IGF1/IGFBP2 stimulates neurogenesis by a mechanism facilitating the binding of IGF1 to its receptor (Brooker et al. 2000). On the contrary, IGFBP4 is generally accepted as a potent inhibitor of IGF1 biological action in most of the in vitro experimental models used (Mazerbourg et al. 2004) and its mRNA has been reported also in fetal neuronal cells (Chernausek et al. 1993). The reason for the increased intensity of the $32-30 \mathrm{kDa}$ doublet, identified as the $N$-glycosylated form of IGFBP4, after the addition of IGF1 remains unclear. In fact, the glycosylation of IGFBP4 does not affect its binding to IGFs and the physiological role of this phenomenon has not been clarified, so far (Zhou et al. 2003). Anyway, the same effect has been previously described in SH-SY5Y neuroblastoma cells (Babajko et al. 1997), suggesting that this differential modulation of IGFBPs by IGF1 could be the result of an autocrine regulatory loop aimed to control cell proliferation.

Furthermore, we found that FNC themselves are able to release immunoreactive IGF1, which is significantly increased by the exposure to $17 \beta$-estradiol $(10 \mathrm{nM})$. The latter finding is in agreement with the reported cross-talk between the IGF system and estrogen in determining neuronal differentiation, survival, adult neurogenesis, and synaptic plasticity (Mendez et al. 2006).
Then, we investigated the effect of high glucose concentrations, which cause many of the pathological consequences of diabetes mellitus, on cell growth and the integrity of the IGF system in FNC cells. Much of the damage induced by glucose is suggested to be a consequence of both high glucose levels as well as glucose fluctuations (Ceriello 1998), which are strong predictors of diabetic microangiopathy, including neuropathy (The Diabetes Control and Complications Trial Research Group 1995). Therefore, FNC were exposed to chronic and intermittent high glucose concentrations, a condition that partially mimics what happens in vivo in diabetic patients. We found that intermittent high glucose inhibited FNC growth whereas stable high glucose did not. Furthermore, apoptosis evaluation indicated that intermittent high glucose induced apoptotic cell death. The stimulatory effects of 20/10 mM glucose on apoptosis were effectively counteracted by IGF1. It is generally accepted that chronic high glucose impairs the rate of neuronal cells growth, as confirmed also by a recent study (Pal et al. 2007); however, some other reports indicated that high glucose is not a potent inducer of neuronal cell death and that neurite regeneration is enhanced by high glucose (Sango et al. 2002). Nevertheless, our data are in agreement with observations from different experimental models, such as fibroblasts, mesangial, tubulointerstitial, and endothelial cells, indicating that glucose variations are more detrimental for cells than stable high glucose (Piconi et al. 2006). Some of these effects probably occur as a result of changes in the secretion or modified local bioavailability of autocrine or paracrine growth factors (Sango et al. 2006). To our knowledge, this is the first demonstration of a negative effect on cell survival in neuronal precursors upon exposure to intermittent high glucose. A possible explanation for this observation may be found in the marked reduction in the release of IGFBP2, but not of IGFBP4, induced by this experimental condition. We reported previously similar results in human retinal endothelial cells (Giannini et al. 2001). IGFBP2, in contrast to IGFBP4, presents sites of association on the matrix/cell surfaces (Bach \& Rechler 1994); thus, it might be hypothesized that one of the mechanisms regulating the levels of IGFBP2 could be a biochemical modification of protein matrix/cell surface or of the components involving the IGFBP heparin-binding sequence. Because of the opposite effects of IGFBP2 and IGFBP4 on the bioavailability of IGF1, it is conceivable that the altered ratio among these two proteins was the determinant of the reduction of cell growth, that we observed upon exposure to intermittent high glucose concentrations. This hypothesis is in agreement also with the reduced amount of IGF1 detected in the culture medium of FNC after treatment with intermittent high glucose. Furthermore, our findings are in keeping with the description of reduced levels of IGF1 and IGFBP2 in the cerebellum of poorly controlled diabetic rats (Busiguina et al. 1996), together with an altered balance between the level of IGF1 in the cerebrospinal fluid and the blood (Armstrong et al. 2000). 
Finally, in our study, we addressed the effect of IGF1 and high glucose concentrations on the expression of the DHCR 24 gene. The expression of this neuroprotective factor had been detected previously in FNC and found to be up-regulated by estrogen (Benvenuti et al. 2005). Interestingly, $17 \beta$-estradiol was also able to induce cell proliferation and counteract $\beta$-amyloid-induced apoptosis in FNC. Thus, it was hypothesized that DHCR24 might be a mediator of these effects (Benvenuti et al. 2005). More recent studies in FNC cells exposed to estrogen after DHCR24 gene silencing confirmed this hypothesis (Luciani et al. 2008). Here, we found that IGF1 significantly up-regulated the amount of DHCR 24 mRNA, whereas high glucose reduced it, thus indicating this factor as a possible mediator of the tropic effects of IGF1 in neuronal cells. This hypothesis, although preliminary, appears to be corroborated by the common intracellular pathways activated by ER- and IGF1R-mediated signaling, involving for instance the MAPK and the PI3K pathways (Mendez et al. 2003, Jover-Mengual et al. 2007).

In conclusion, our results indicate for the first time that intermittent high glucose concentrations, similar to those observed in poorly controlled diabetic patients, may contribute to the development of diabetic neuropathy by interfering with the tropic effects exerted by the IGF system, and suggest the involvement of the pro-survival factor DHCR24. Nevertheless, additional studies, performed for instance in cells subjected to DHCR24 gene silencing, are needed to clarify the exact role of DHCR24 in mediating the effects of IGF1 and high glucose in neuronal cells.

\section{Declaration of Interest}

The authors declare that there is no conflict of interest that could be perceived as prejudicing the impartiality of the research reported.

\section{Funding}

This study was partially supported by grants from Ministero dell'Università $\mathrm{e}$ della Ricerca Scientifica (programmi di Ricerca Scientifica di Rilevante Interesse Nazionale, PRIN2006, coordinator Prof. Alessandro Peri), Regione Toscana (TRESOR project, responsible Prof. Mario Serio), and Ente Cassa di Risparmio di Firenze.

\section{References}

Armstrong CS, Wuarin L \& Ishii DN 2000 Uptake of circulating insulin-like growth factor-I into the cerebrospinal fluid of normal and diabetic rats and normalization of IGF-II mRNA content in diabetic rat brain. Journal of Neuroscience Research 59 649-660.

Babajko S, Leneuve P, Loret C \& Binoux M 1997 IGF-binding protein-6 is involved in growth inhibition in SH-SY5Y human neuroblastoma cells: its production is both IGF- and cell density-dependent. Journal of Endocrinology 152 221-227.

Bach LA \& Rechler MM 1994 Insulin-like growth factors and diabetes. Diabetes/Metabolism Reviews 3 228-257.

Benvenuti S, Luciani P, Vannelli GB, Gelmini S, Franceschi E, Serio M \& Peri A 2005 Estrogen and selective estrogen receptor modulators exerts neuroprotective effects and stimulate the expression of selective Alzheimer's disease indicator-1, a recently discovered antiapoptotic gene, in human neuroblast long-term cell cultures. Journal of Clinical Endocrinology and Metabolism 90 1775-1782.

Brooker GJ, Kalloniatis M, Russo VC, Murphy M, Werther GA \& Bartlett PF 2000 Endogenous IGF-I regulates the neuronal differentiation of adult stem cells. Journal of Neuroscience Research 59 332-341.

Busiguina S, Chowen JA, Argente J \& Torres-Aleman I 1996 Specific alterations of the insulin-like growth factor I system in the cerebellum of diabetic rats. Endocrinology 137 4980-4987.

Ceriello A 1998 The emerging role of post-prandial hyperglycemic spikes in the pathogenesis of diabetic complications. Diabetic Medicine 15 188-193.

Chernausek SD, Murray MA \& Cheung PT 1993 Expression of insulin-like growth factor binding protein-4 (IGFBP-4) by rat neural cells-comparison to other IGFBPs. Regulatory Peptides 48 123-132.

Cho HJ, Kim WK, Kim EJ, Jung KC, Park S, Lee HS, Tyner AL \& Park JK 2003 Conjugated linoleic acid inhibits cell proliferation and ErbB3 signaling in HT-29 human colon cell line. American Journal of Physiology 284 G996-G1005.

Daughaday WH, Mariz IK \& Blethen SL 1980 Inhibition of access of bound somatomedin to membrane receptor and immunobinding sites: a comparison of radioreceptor and radioimmunoassay of somatomedin in native and acid-ethanol-extracted serum. Journal of Clinical Endocrinology and Metabolism $\mathbf{5 1}$ 781-788.

D'Ercole AJ, Ye P, Calikoglu AS \& Gutierrez-Ospina G 1996 The role of the insulin-like growth factors in the central nervous system. Molecular Neurobiology 13 227-255.

Gammeltoft S, Haselbacher GK, Humbel RE, Fehlman M \& Van Obberghen E 1985 Two types of receptors for insulin-like growth factors in mammalian brain. EMBO Journal 4 3407-3412.

Giannini S, Mohan S, Galli G, Rotella CM, LeBon TR \& Fujita-Yamaguchi Y 1994 Characterization of insulin-like growth factor binding proteins (IGFBPs) produced by cultured fibroblasts from patients with NIDDM, IDDM and obesity. Journal of Clinical Endocrinology and Metabolism 79 1824-1830.

Giannini S, Cresci B, Pala L, Ciucci A, Manuelli C, Fujita-Yamaguchi Y, Cappugi P \& Rotella CM 1999 Human glomerular endothelial cells IGFBPs are regulated by IGF-I and TGF $\beta 1$. Molecular and Cellular Endocrinology 154 123-136.

Giannini S, Cresci B, Pala L, Ciucci A, Franchini A, Manuelli C, FujitaYamaguchi Y, Cappugi P, Zonefrati R \& Rotella CM 2001 IGFBPs modulate IGF-I, and high glucose-controlled growth of human retinal endothelial cells. Journal of Endocrinology 171 273-284.

Greeve I, Hermans-Borgmeyer I, Brellinger C, Kasper D, Gomez-Isla T, Behl C, Levkau B \& Nitsch RM 2001 The human DIMINUTO/DWARF1 homolog seladin-1 confers resistance to Alzheimer's disease-associated neurodegeneration and oxidative stress. Journal of Neuroscience $\mathbf{2 0}$ $7345-7352$.

Gustafsson H, Soderdahl T, Jonsson G, Bratteng JO \& Forsby A 2004 Insulinlike growth factor type 1 prevents hyperglycemia-induced uncoupling protein 3 down-regulation and oxidative stress. Journal of Neuroscience Research 77 285-291.

Han VK, Matsell DG, Delhanty PJ, Hill DJ, Shimasaki S \& Nygard K 1996 IGF-binding proteins mRNAs in the human fetus: tissue and cellular distribution of developmental expression. Hormone Research 45 160-166.

Ho EC, Lam KS, Chen YS, Yip JC, Arvindakshan M, Yamagishi S, Yagihashi S, Oates PJ, Ellery CA, Chung SS et al. 2006 Aldose reductase-deficient mice are protected from delayed motor nerve conduction velocity, increased c-Jun NH2-terminal kinase activation, depletion of reduced glutathione, increased superoxide accumulation, and DNA damage. Diabetes 55 1946-1953.

Hossenlop P, Seurin D, Segovia-Quinson B, Hardouin S \& Binoux M 1986 Analysis of serum insulin-like growth factor binding protein using western blotting: use of the method for titration of the binding proteins and competitive binding studies. Analytical Biochemistry 154 138-143. 
Jover-Mengual T, Zukin RS \& Etgen AM 2007 MAPK signaling is critical to estradiol protection of CA1 neurons in global ischemia. Endocrinology 148 1131-1143.

Kim EJ, Holthuizen PE, Kim J \& Park JH 2005 Overexpression of mature insulin-like growth factor (IGF)-II leads to growth arrest in Caco-2 human colon cancer cells. Growth Hormone and IGF Research 15 64-71.

Kummer JL, Zawada WM, Freed CR, Chernausek SD \& Heidenreich KA 1996 Insulin-like growth factor binding proteins in fetal rat mesencefalic cultures: regulation by fibroblast growth factor and insulin-like growth factor I. Endocrinology 137 3551-3556.

Liotta F, Angeli R, Cosmi L, Filì L, Manuelli C, Frosali F, Mazzinghi B, Maggi L, Pasini A, Lisi V et al. 2008 TLR3 and TLR4 are expressed by human bone marrow-derived mesenchymal stem cells and can inhibit their T-cell modulatory activity by impairing Notch signaling. Stem Cells 26 278-289.

Luciani P, Ferruzzi P, Arnaldi G, Crescioli C, Benvenuti S, Valeri A, Greeve I, Serio M, Mannelli M \& Peri A 2004 Expression of the novel adrenocorticotropin-responsive gene selective Alzheimer's disease indicator-1 in the normal adrenal cortex and in adrenocortical adenomas and carcinomas. Journal of Clinical Endocrinology and Metabolism $\mathbf{8 9}$ 1332-1339.

Luciani P, Deledda C, Rosati F, Benvenuti S, Cellai I, Dichiara F, Morello M, Vannelli GB, Danza G, Serio M et al. 2008 Seladin-1 is a fundamental mediator of the neuroprotective effects of estrogen in human neuroblast long-term cell cultures. Endocrinology (DOI. 10.1210/en.2007.1795).

Maggi M, Barni T, Fantoni G, Mancina R, Pupilli C, Luconi M, Crescioli C, Serio M \& Vannelli GB 2000 Expression of biological effects endothelin-1 in human gonadotropin-releasing hormone- secreting neurons. Journal of Clinical Endocrinology and Metabolism 85 1685-1665.

Matthews CC \& Feldman EL 1996 Insulin-like growth factor I rescues SH-SY5Y human neuroblastoma cells from hyperosmotic induced programmed cell death. Journal of Cellular Physiology 166 323-331.

Matthews CC, Odeh HM \& Feldman EL 1997 Insulin-like growth factor-I is an osmoprotectant in human neuroblastoma cells. Neuroscience 79 525-534.

Mazerbourg S, Callebaut I, Zapf J, Mohan S, Overgaard M \& Monget P 2004 Up date on IGFBP-4: regulation of IGFBP-4 levels and functions, in vitro and in vivo. Growth Hormone and IGF Research 14 71-84.

Mendez P, Azcoitia I \& Garcia-Segura LM 2003 Estrogen receptor $\alpha$ forms estrogen-dependent multimolecular complexes with insulin-like growth factor receptor and phosphatidylinositol 3-kinase in the adult rat brain. Brain Research. Molecular Brain Research 112 170-176.

Mendez P, Wandosell F \& Garcia-Segura LM 2006 Cross-talk between estrogen receptors and insulin-like growth factor-I receptor in the brain: cellular and molecular mechanisms. Frontiers in Neuroendocrinology 27 391-403.

Menouny M, Binoux M \& Babajko S 1997 Role of insulin-like growth factor binding protein-2 and its proteolysis in neuroblastoma cell proliferation: modulation by transforming growth factor- $\beta$ and retinoic acid. Endocrinology 138 683-690.

Mohan S \& Baylink DJ 2002 IGF-binding proteins are multifunctional and act via IGF-dependent and -independent mechanisms. Journal of Endocrinology 175 19-31.

Naeve GS, Vana AM, Eggold JR, Verge G, Ling N \& Foster AC 2000 Expression of rat insulin-like growth binding protein-6 in the brain, spinal cord, and sensory ganglia. Brain Research. Molecular Brain Research 75 185-197.

Pal L, Chu H-P, Shu J, Topalli I, Santoro N \& Karkanias G 2007 In vitro evidence of glucose-induced toxicity in $\mathrm{GnRH}$ secreting neurons: high glucose concentrations influence GnRH secretion, impair cell viability and induce apoptosis in the GT1-1 neuronal cell line. Fertility and Sterility 88 1143-1149.
Piconi L, Quagliaro L, Assaloni R, Da Ros R, Maier A, Zuodar G \& Ceriello A 2006 Constant and intermittent high glucose enhances endothelial cells apoptosis through mitocondrial superoxide overproduction. Diabetes/ Metabolism Research and Reviews 22 198-203.

Pons S \& Torres-Aleman I 1992 Basic fibroblast factor modulates insulin-like growth factor-I, its receptor, and its binding proteins in hypothalamic cell cultures. Endocrinology 131 2271-2278.

Roghani M, Hossenlop M, Lepade P, Balland A \& Binoux M 1993 Isolation from human cerebrospinal fluid of a new insulin-like growth factor binding protein with a selective affinity for IGF-II. FEBS Letters 255 253-258.

Russo VC, Kobayashi K, Najdovska S, Baker NL \& Werther GA 2004 Neuronal protection from glucose deprivation via modulation of glucose transport and inhibition of apoptosis: a role for the insulin-like growth factor system. Brain Research 1009 40-53.

Russo VC, Gluckman PD, Feldman EL \& Werther GA 2005 The Insulin-like growth factor system and its pleiotropic functions in brain. Endocrine Reviews 26 916-943.

Sango K, Horie H, Saito H, Ajiki K, Tokashiki A, Takeshita K, Ishigatsubo Y, Kawano H \& Ishikawa Y 2002 Diabetes is not a potent inducer of neuronal cell death in mouse sensory ganglia, but it enhances neurite regeneration in vitro. Life Sciences 71 2351-2368.

Sango K, Suzuki T, Yaganisawa H, Takaku S, Hirooka H, Tamura M \& Watabe K 2006 High glucose-induced activation of the polyol pathway and changes of gene expression profiles in immortalized adult mouse Schwann cells IMS32. Journal of Neurochemistry 98 446-458.

The Diabetes Control and Complications Trial Research Group 1995 The effect of intensive diabetes therapy on the development and progression of neuropathy. Annals of Internal Medicine 122 561-568.

Tomlinson DR \& Gardiner NJ 2008 Glucose neurotoxicity. Nature Reviews. Neuroscience 9 36-45.

Toth C, Brussee V, Cheng C \& Zochodne DW 2004 Diabetes mellitus and sensory neuron. Journal of Neuropathology and Experimental Neurology 63 561-573.

Vannelli GB, Ensoli F, Zonefrati R, Kubota Y, Arcangeli A, Becchetti A, Camici G, Barni T, Thiele CJ \& Balboni GC 1995 Neuroblast long-term cell cultures from human fetal olfactory epithelium respond to odors. Journal of Neuroscience 15 4382-4394.

Vincent AM, Russell JW, Low P \& Feldman EL 2004 Oxidative stress in the pathogenesis of diabetic neuropathy. Endocrine Reviews 25 612-628.

Willaime-Morawek S, Arbez N, Mariani J \& Brugg B 2005 IGF-I protects cortical neurons against ceramide-induced apoptosis via activation of the $\mathrm{PI}-3 \mathrm{~K} / \mathrm{Akt}$ and ERK pathways; is this protection independent of CREB and Bcl-2? Brain Research. Molecular Brain Research 142 97-106.

Yagihashi S, Kamijo M \& Watanabe K 1990 Reduced myelinated fiber size correlates with loss of axonal neurofilaments in peripheral nerve of chronically strptozotocin diabetic rats. American Journal of Pathology $\mathbf{1 3 6}$ 1365-1373.

Zhou H, Hughes DE, Major ML, Yoo K, Pesold C \& Costa RH 2001 Atypical mouse cerebellar development is caused by ectopic expression of the forkhead box transcription factor HNF-3 $\beta$. Gene Expression 9 217-236.

Zhou R, Diehl D, Hoeflich A, Lahm H \& Wolf E 2003 IGF-binding protein4: biochemical characteristic and functional consequences. Journal of Endocrinology 178 177-193.

Received in final form 4 July 2008

Accepted 8 July 2008

Made available online as an Accepted Preprint 8 July 2008 